\title{
Antibacterial Activity of Validamycin A against Pseudomonas solanacearum and Its Efficacy against Tomato Bacterial Wilt
}

\author{
Ryo ISHIKAWA*, Kenichi FUJIMORI* and Kazuho MATSUURA*
}

\begin{abstract}
Validamycin A (VM-A), the active ingredient of Validacin ${ }^{\circledR}$, inhibits fungal growth by inhibiting trehalase activity. Therefore, VM-A was tested against Pseudomonas solanacearum for its efficacy in controlling tomato bacterial wilt. In media containing trehalose as the sole carbohydrate, VM-A at 50 $\mu \mathrm{g} / \mathrm{ml}$ inhibited growth of $P$. solanacearum to rates similar to that of the bacteria in media without carbohydrate for seven days after inoculation. VM-A also gave excellent control of tomato bacterial wilt in greenhouse pot tests, when directly injected into plant stems. In field tests, foliar sprays of VM-A at $250 \mu \mathrm{g} / \mathrm{ml}$ five days before and two days after inoculation had reduced disease by $47.4 \%$ by four weeks after inoculation. In the tomato stem between 0 and $5 \mathrm{~cm}$ above the soil line, the bacteria population in the non-treated plot reached $3.84 \times 10^{10} \mathrm{cfu} / \mathrm{g}$ fresh weight, whereas that in the VM-A $(500 \mu \mathrm{g} / \mathrm{ml})$-treated plot reached $2.13 \times 10^{9} \mathrm{cfu} / \mathrm{g}$ fresh weight. Inhibition of bacteria growth by VM-A may delay the appearance of disease symptoms of tomato bacterial wilt.
\end{abstract}

(Received February 13, 1996 ; Accepted July 23, 1996)

Key words : validamycin A, Pseudomonas solanacearum, control of tomato bacterial wilt.

\section{INTRODUCTION}

Bacterial wilt caused by Pseudomonas solanacearum is one of the most serious diseases affecting several hundreds species of crops in tropical, subtropical and temperate regions ${ }^{2,4)}$ by producing a slime which clogs the xylem and results in wilting. Pseudomonas solanacearum is soil-borne or carried on debris of diseased roots and stems. In order to control the disease, the soil must be sterilized by solarization or with chemicals such as methyl bromide or chlorpicrin, either independently or in combination. However, soil sterilization does not completely control the disease because chemicals are absorbed by soil particles and degraded by microorganisms. Moreover, under conditions of incomplete vaporization in the soil, methyl bromide and chlorpicrin fumigation can be irritating and phytotoxic. Therefore, they can not be used after the disease occurs in the fields. Furthermore, because methyl bromide affects the ozone layer, its application is controlled. No chemical controls bacterial wilt in culture.

Validamycin A (VM-A), the active ingredient of Validacin ${ }^{\circledR}$, gives excellent control against rice sheath blight caused by Rhizoctonia solani by inhibiting the hyphal growth of the pathogen on rice leaves. VM-A does not exhibit antifungal activity on potato sucrose agar or potato dextrose agar medium unless the medium contains trehalose, a transport sugar in $R$. solani, as the sole carbohydrate. Moreover, it inhibits $R$. solani trehalase activity in vitro ${ }^{1,6)}$. The penetration hyphae of $R$. solani in rice sheath absorb carbohydrates and change them into trehalose ${ }^{7}$, which is transported to hyphal tips, where it is metabolized into two molecules of glucose by trehalase. By inhibiting trehalase activity in the hyphal tips of $R$. solani, a shortage of utilizable carbohydrate results in the inhibition of hyphal elongation.

In this report antibacterial activity of VM-A against $P$. solanacearum and its control of tomato bacterial wilt after various methods of applications were examined. The distribution and population growth of $P$. solanacearum in tomato stems after VM-A treatments was also studied.

\section{MATERIALS AND METHODS}

Materials. Pseudomonas solanacearum E.F. Smith, strain OE1-1 was obtained from Dr. H. Date of Okayama Prefecture Agricultural Experiment Station. Tomato (Lycopersicon esculentum Mill. cv. Oogatafukuju) seeds were purchased from Takii Seed Corporation. Trehalose and thyrothricin were purchased from Sigma Chemical Company, triphenyl tetrazolium chloride (TTC), polymyxin B sulfate, chloromycetin and polypeptone were purchased from Wako Pure Chemical Ind. Ltd., and casamino acid was purchased from DIFCO Laboratories. Crystal violet was purchased from Merck

\footnotetext{
* Agricultural Research Laboratories, Agro-Company, Takeda Chemical Industries, Ltd., 10 Wadai, Tsukuba 300-42, Japan 武田薬品工業株式会社, 農業科学研究所
} 
\& Co., Inc. VM-A used throughout this study was $97 \%$ in purity.

Tomato plants were transplanted into $6 \mathrm{~cm}$-diameter pots three weeks after seeding, then grown for four weeks in a greenhouse. The pathogen was maintained in sterile water at room temperature. Bacterial suspensions for the experiments were incubated in casamino acid-polypeptone-sucrose medium (CPS; 0.1, 1.0, 0.5\%) at $34^{\circ} \mathrm{C}$ for seven days. For colony counts, $0.005 \%$ TTC was added to CPS agar medium ${ }^{5}$.

Antibacterial activity in vitro. Czapek medium

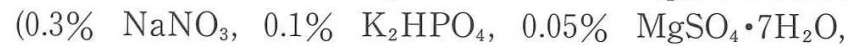
$\left.0.05 \% \quad \mathrm{KCl}, \quad 0.001 \% \quad \mathrm{FeSO}_{4} \cdot 7 \mathrm{H}_{2} \mathrm{O}\right)$, containing $0.8 \%$ carbohydrate, used for testing antibacterial activity against $P$. solanacearum. An $8 \mathrm{~mm}$-diameter paper disk, containing about $30 \mu \mathrm{l}$ VM-A solution, was placed on 10 $\mathrm{ml}$ of Czapek-trehalose agar medium in which $P$. solanacearum was embedded. After four days of incubation at $34^{\circ} \mathrm{C}$, the diameter of the inhibitory zone was measured.

To $10 \mathrm{ml}$ of Czapek liquid medium containing either $0.5 \%$ mannitol, glucose, mannose, inositol, sucrose, pyruvic acid, glycerol, galactose or trehalose as the sole carbohydrate, VM-A in 70\% ethanol was added to make a final concentration of $50 \mu \mathrm{g} / \mathrm{ml}$. The medium was inoculated with $100 \mu \mathrm{l}$ of bacterial cells at a concentration of about $10^{4} \mathrm{cfu} / \mathrm{ml}$, then incubated at $30^{\circ} \mathrm{C}$ for eight days in an incubator. Using a dilution plate technique on CPS-TTC agar medium, the number of bacteria in the medium containing trehalose was counted $0,1,3,5$ and 8 days after inoculation, but only after eight days for the media containing other carbohydrates.

Pot test in a greenhouse. Tomato plants were transplanted into $1 / 5000$ a Wagner's pots three weeks after seeding, then grown for six weeks in the greenhouse. A paste of $5 \%$ VM-A was made with $70 \% \mathrm{CaCO}_{3}$ and $25 \%$ water. Tomato stems were pierced with a mini-drill to make a hole $10 \mathrm{~cm}$ above the soil line or just below the first inflorescence (at $30 \mathrm{~cm}$ above the soil line), which was filled with $0.2 \mathrm{~g}$ of VM-A paste using a syringe. VM-A paste was applied to nine tomato stems with two replicates. Seven days later, tomato plants were inoculated with $10^{8} \mathrm{cfu} / \mathrm{ml}$ of $P$. solanacearum by pouring $500 \mathrm{ml}$ of the bacterial suspension on the soil in each pot. The number of wilted plants was counted daily until 20 days after inoculation.

Field test. A field test using VM-A foliar sprays against tomato bacterial wilt was carried out in 1994 at Ibaraki Prefecture. The tomato cv. Oogatafukuju was seeded on May 20, and transplanted to the field on June 29. Foliar spray of VM-A solution at 250 or $500 \mu \mathrm{g} / \mathrm{ml}$ was applied to 20 tomato plants in a plot on July 29 and August 5 . The soil in each pot was drenched with $100 \mathrm{ml}$ of $1.8 \times 10^{8} \mathrm{cfu} / \mathrm{ml}$ P. solanacearum on August 3. A daily disease index for each plant was assigned according to the following scale : 0 : no symptom, 1 : slight wilt on the top part of the plant, $2:$ slight wilt in leaves, $3:$ severe wilt of the whole plant, $4:$ death of the plant.
Hydroponics culture test. Hydroponics water contained $\quad 0.033 \% \quad \mathrm{KNO}_{3}, \quad 0.0167 \% \quad \mathrm{Ca}\left(\mathrm{NO}_{3}\right)_{2} \cdot 4 \mathrm{H}_{2} \mathrm{O}$, $0.0098 \% \quad \mathrm{KH}_{2} \mathrm{PO}_{4}, \quad 0.015 \% \quad \mathrm{MgSO}_{4} \cdot 7 \mathrm{H}_{2} \mathrm{O}, \quad 0.0075 \%$ $\mathrm{NH}_{4} \mathrm{NO}_{3}$ and $0.0025 \%$ Greenplus ${ }^{\circledR}$ (Kyodo Hiryo) in deionized water. Roots of five-week-old tomato plants were washed well to remove soil and transplanted to hydroponics culture in trays. VM-A was mixed with the hydroponics culture water to obtain a final concentration of $100 \mu \mathrm{g} / \mathrm{ml}$ seven days after transplanting. Three hours later, a suspension of bacteria in distilled water was added to the hydroponics culture water to reach a final concentration of $2.4 \times 10^{7} \mathrm{cfu} / \mathrm{ml}$. The culture water was replaced seven days after inoculation.

Bacterial distribution in tomato stems. Sixweek-old tomato plants, cv. Oogatafukuju, were transplanted to $1 / 20,000$ a Wagner's pots in a greenhouse. Their leaves were then sprayed to run-off with VMI-A solution at $500 \mu \mathrm{g} / \mathrm{ml}$. One week later, each plant was inoculated with $50 \mathrm{ml}$ of a bacterial suspension $\left(5 \times 10^{8}\right.$ $\mathrm{cfu} / \mathrm{ml}$ ) by soil drench. Tomato stems were excised $5 \mathrm{~cm}$ above the soil, then cut into fragments of several millimeters 10 days after inoculation. The pieces were immersed in $100 \mathrm{ml}$ of distilled water to exude the bacteria and kept overnight at $6^{\circ} \mathrm{C}$ to avoid contamination by other bacteria and inhibit growth of $P$. solanacearum. The number of bacteria was counted by dilution plating after three days of incubation at $30^{\circ} \mathrm{C}$ on a selective medium containing. CPS-TTC, crystal violet $(50 \mu \mathrm{g} / \mathrm{ml})$, polymyxin B sulfate $(100 \mu \mathrm{g} / \mathrm{ml})$, thyrothricin $(20 \mu \mathrm{g} /$ ml) and chloromycetin $(5 \mu \mathrm{g} / \mathrm{ml})^{3)}$.

\section{RESULTS}

\section{Antibacterial activity of VM-A in vitro}

After seven days of incubation at $30^{\circ} \mathrm{C}$, VM-A inhibited bacterial multiplication only in media containing

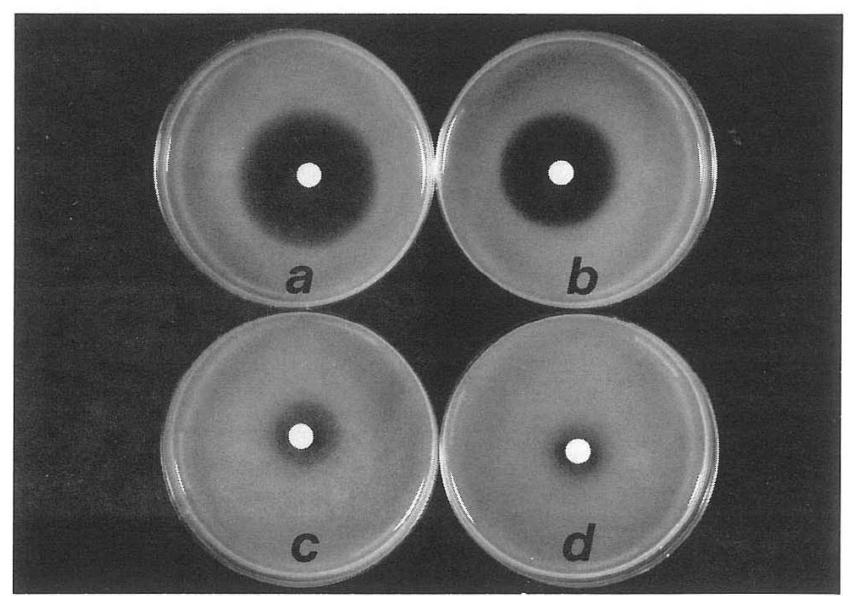

Fig. 1. Antibacterial activity of validamycin A against Pseudomonas solanacearum OE1-1 embedded in Czapek agar medium containing trehalose as the sole carbohydrate. A paper disk contains about $30 \mu 1$ of validamycin A solution. a, validamycin A $500 \mu \mathrm{g} / \mathrm{ml}$; b, $250 \mu \mathrm{g} / \mathrm{ml}$; c, 125 $\mu \mathrm{g} / \mathrm{ml} ; \mathrm{d}, 62.5 \mu \mathrm{g} / \mathrm{ml}$. 
trehalose as the sole carbohydrate (Fig. 1). VM-A inhibited bacteria at $62.5 \mu \mathrm{g} / \mathrm{ml}$, the lowest concentration in this test. VM-A did not inhibit the multiplication of $P$. solanacearum in media containing mannitol, glucose, mannose, inositol, sucrose, pyruvic acid, glycerol or

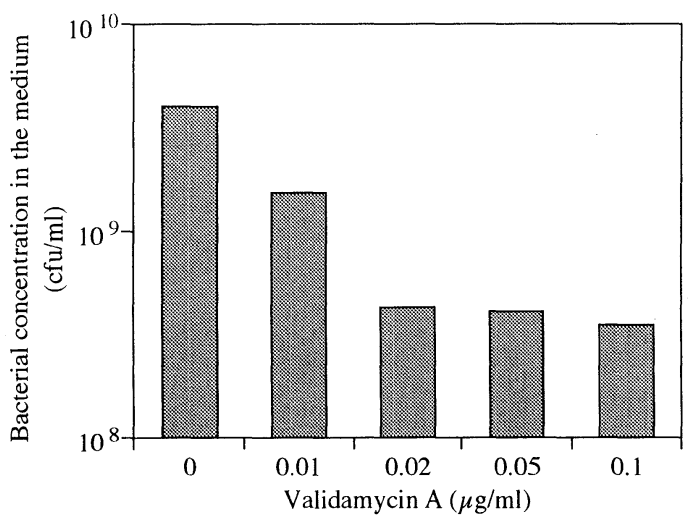

Fig. 2. Antibacterial activity of validamycin A against Pseudomonas solanacearum OE1-1 in Czapek liquid medium containing trehalose as the sole carbohydrate. To $10 \mathrm{ml}$ of Czapek liquid medium containing $0.5 \%$ trehalose as the sole carbohydrate, $100 \mu \mathrm{l}$ of validamycin A in $70 \%$ ethanol was added. $P$. solanacearum was added to the media for a final concentration of $7-8 \times$ $10^{2} \mathrm{cfu} / \mathrm{ml}$. The media were incubated at $30^{\circ} \mathrm{C}$ for eight days in an incubator. The number of bacteria was counted by dilution plate technique on casein-peptone-sucrose-TTC media. Bars are the means of three replicates.

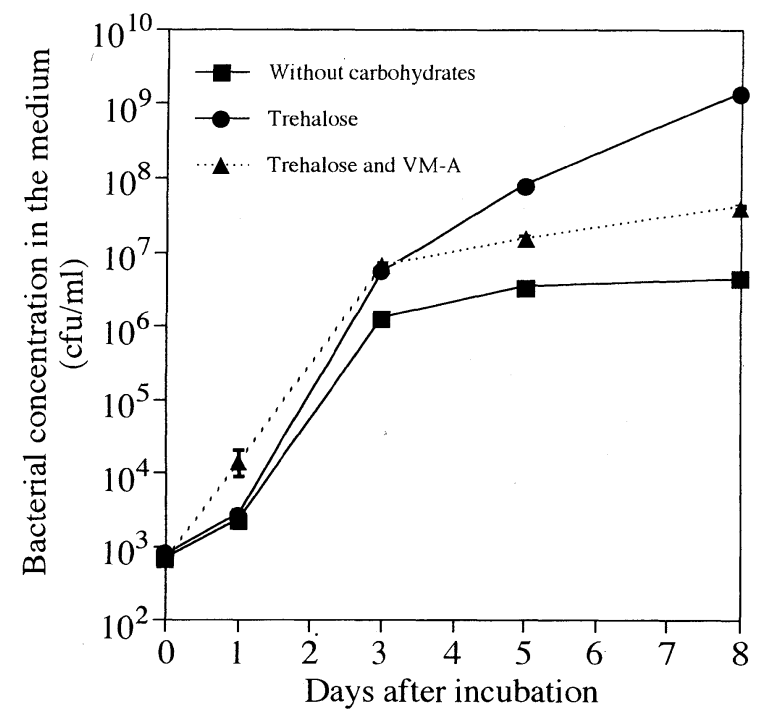

Fig. 3. Effect of $50 \mu \mathrm{g} / \mathrm{ml}$ validamycin A (VM-A) on the growth of Pseudomonas solanacearum in 10 $\mathrm{ml} \mathrm{Czapek} \mathrm{liquid} \mathrm{medium} \mathrm{containing} 0.5 \%$ trehalose as the sole carbohydrate. The liquid media were incubated at $30^{\circ} \mathrm{C}$ for eight days in an incubator. After dilution plating on CPSTTC agar medium, bacteria were counted at 0 , 1, 3, 5 and 8 days after inoculation. Bars indicate standard errors of three replicates. galactose as the sole carbohydrate (data not shown).

In liquid media containing trehalose as the sole carbohydrate, VM-A strongly inhibited the multiplication of bacteria at concentrations of $0.02 \mu \mathrm{g} / \mathrm{ml}$ and above (Fig. 2). VM-A at the concentration of $0.02 \mu \mathrm{g} / \mathrm{ml}$ reduced multiplication of $P$. solanacearum to $10 \%$ of the growth attained when VM-A was not present. Through the entire eight days of the test period, the number of bacteria increased exponentially to $1.46 \times 10^{9} \mathrm{cfu} / \mathrm{ml}$ (Fig. 3). In the Czapek-trehalose medium with $50 \mu \mathrm{g} / \mathrm{ml}$ of VM-A, however, the number of bacteria increased exponentially for three days, reaching $6.94 \times 10^{6} \mathrm{cfu} / \mathrm{ml}$. Thereafter, they remained in a stationary phase at $1.59 \times 10^{7} \mathrm{cfu} / \mathrm{ml}$. Without a carbohydrate present, $P$. solanacearum also multiplied exponentially for three days, but only reached a population of $1.32 \times 10^{6} \mathrm{cfu} / \mathrm{ml}$. Thereafter, little increase was observed. Growth rates in the media containing trehalose and VM-A were six times higher than that in the media without a carbohydrate and in the media with trehalose during the first day of incubation. Thereafter, populations in media containing trehalose and VM-A were almost the same as those in the medium without a carbohydrate.

\section{Pot test in a greenhouse}

Wilted tomato plants were first observed six days after inoculation in the non-treated plot (Fig. 4). Direct injection of the VM-A paste into stems $10 \mathrm{~cm}$ above the soil (AS) seven days before inoculation inhibited wilting symptoms until 12 days after inoculation. Injecting the paste below the first inflorescence (BI) seven days before inoculation inhibited disease development throughout

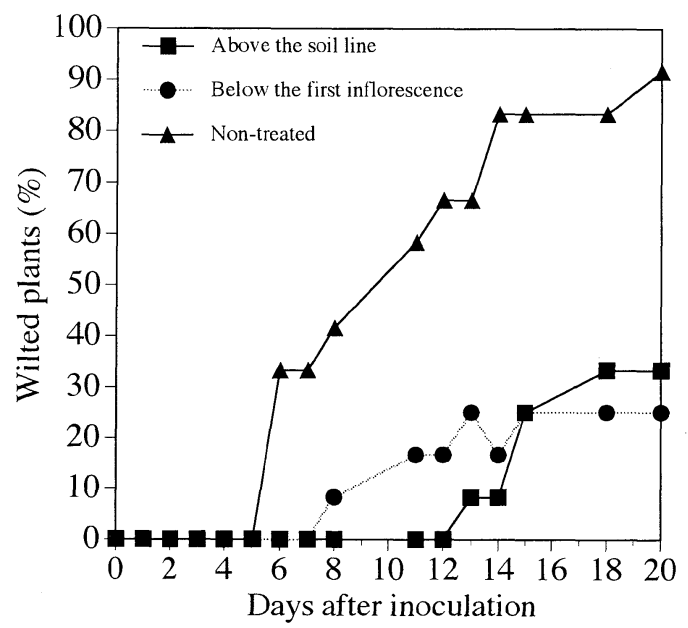

Fig. 4. Effect of validamycin A (VM-A) against tomato bacterial wilt in greenhouse pot tests. A tomato stem was pierced with a mini-drill to make a hole into which $0.2 \mathrm{~g}$ validamycin A paste $(5 \%$ VM-A, $70 \% \mathrm{CaCO}_{3}$, 25\% water) was syringed. VM-A paste was applied to nine tomato stems with two replicates either $10 \mathrm{~cm}$ above the soil or just below the first inflorescence (at $30 \mathrm{~cm}$ above the soil line) seven days before the soil was drenched with a $500 \mathrm{ml}$ bacterial suspension $\left(1 \times 10^{8} \mathrm{cfu} / \mathrm{ml}\right)$. 
the course of the experiment. After 20 days, $91.7 \%$ of the control plants had wilted, as opposed to $33.3 \%$ of those treated AS and only $25.0 \%$ of those treated BI. Both VM-A treatments by direct injection into the stem, either near (at $10 \mathrm{~cm}$ above the soil line) or far from the soil line (below the first inflorescence) were effective in delaying and reducing tomato bacterial wilt.

\section{Field test}

In the non-treated plot, wilting occurred by seven days after inoculation. The disease severity of non-treated control tomato plants 15 and 23 days was $56 \%$ and $90 \%$, respectively (Fig. 5). Almost all the plants died by 28 days.

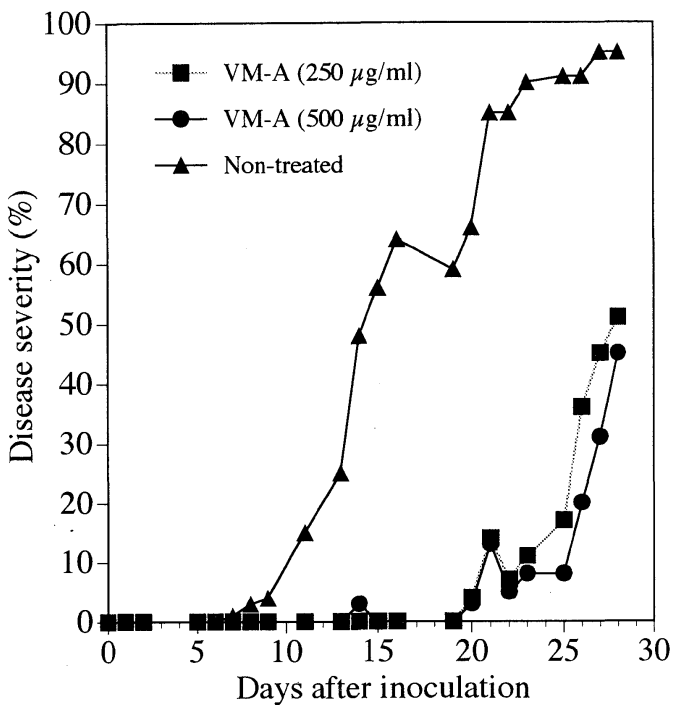

Fig. 5. Control of tomato bacterial wilt by foliar sprays of validamycin A (VM-A) in field tests. Twenty tomato plants (cv. Oogatafukuju) in two replicates were sprayed to run-off with 100 $\mathrm{ml}$ per plant of VM-A solution on July 29 and August 5 in 1994. On August 3 each tomato plant was inoculated with a soil drench of $100 \mathrm{ml}$ of a bacterial suspension $\left(1.8 \times 10^{8} \mathrm{cfu} / \mathrm{ml}\right)$. Disease severity for each plant was rated daily until 28 days after inoculation according to the following: 0 , no symptom; 1 , slight wilt on the upper part of the plant; 2 , slight wilt in leaves; 3 , severe wilt of the whole plant; 4 , death of the plant.
Foliar spraying with VM-A at $250 \mu \mathrm{g} / \mathrm{ml}$ and $500 \mu \mathrm{g} /$ $\mathrm{ml}$ resulted in wilted tomato plants by 20 days after inoculation. By 28 days, disease severity in the VM-A treated plot at $250 \mu \mathrm{g} / \mathrm{ml}$ was $51 \%$ and at $500 \mu \mathrm{g} / \mathrm{ml}$ was $45 \%$. VM-A delayed the appearance of disease symptoms for about 10 to 14 days.

\section{Hydroponics culture test}

In the hydroponics culture test, all the non-treated Oogatafukuju plants had wilted after nine days (Table 1 ). On the other hand, only $25 \%$ of the plants in the VM-A-treated plot had wilted after 12 days. By 12 days, $83 \%$ of the non-treated Patio cultivar had wilted. VM-A completely inhibited wilting until eight days when only $8 \%$ of the plants had wilted. No further increase in wilting was observed.

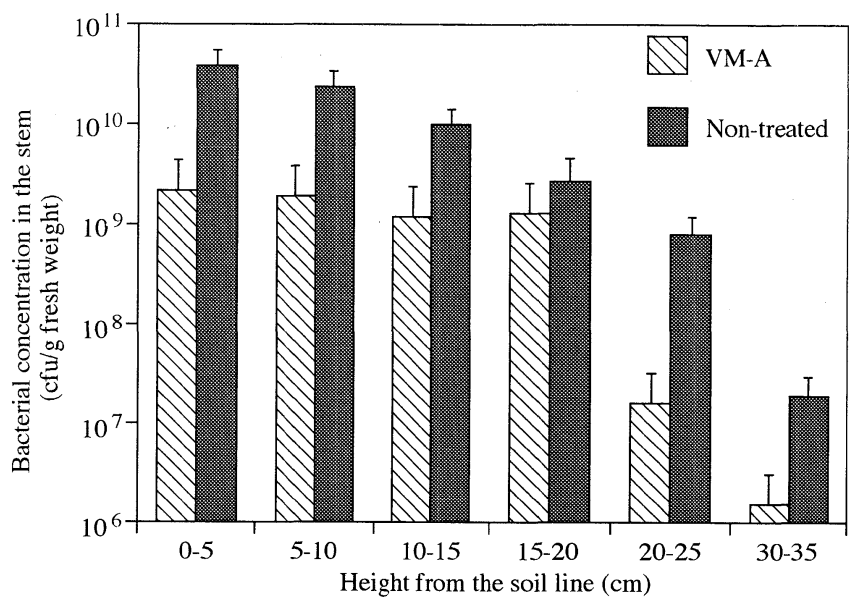

Fig. 6. Effect of foliar sprays of $500 \mu \mathrm{g} / \mathrm{ml}$ validamycin A (VM-A) on the distribution of Pseudomonas solanacearum in tomato stems. One week after application, each tomato plant was inoculated by soil drench with $50 \mathrm{ml}$ of a bacterial suspension $\left(5 \times 10^{8} \mathrm{cfu} / \mathrm{ml}\right)$. Ten days after inoculation tomato stems were excised at $5 \mathrm{~cm}$ intervals, then cut into fragments several millimeters thick, then immersed in $100 \mathrm{ml}$ of distilled water. The number of bacteria from the tomato stem was counted by dilution plating on a selective medium for $P$. solanacearum. Bars indicate standard errors of three replicates.

Table 1. Efficacy of validamycin A (VM-A) against tomato bacterial wilt in hydroponics culture

\begin{tabular}{|c|c|c|c|c|c|c|c|}
\hline \multirow{2}{*}{ Cultivar } & \multirow{2}{*}{$\begin{array}{c}\text { VM-A } \\
\text { treatment }\end{array}$} & \multicolumn{6}{|c|}{$\%$ of wilted tomato plants } \\
\hline & & $\mathrm{DAI}^{\mathrm{a})}$ & 6 & 7 & 8 & 9 & 12 \\
\hline \multirow[t]{2}{*}{ Oogatafukuju } & + & & 12.5 & 12.5 & 12.5 & 12.5 & $25.0 \mathrm{a}^{\mathrm{b}}$ \\
\hline & - & & 62.5 & 87.5 & 87.5 & 100.0 & $100.0 \mathrm{~b}$ \\
\hline \multirow[t]{2}{*}{ Patio } & + & & 0.0 & 0.0 & 8.3 & 8.3 & $8.3 \mathrm{c}$ \\
\hline & - & & 16.6 & 41.6 & 58.3 & 66.7 & $83.3 \mathrm{~d}$ \\
\hline
\end{tabular}

a) DAI means days after inoculation. For cv. Oogatafukuju eight plants were tested and for cv. Patio, 12 plants. VM-A was dissolved in hydroponics water at a concentration of $100 \mu \mathrm{g} / \mathrm{ml}$. Three hours after application, the bacterial suspension was poured into hydroponics water at a final concentration of $2.4 \times 10^{7} \mathrm{cfu} / \mathrm{ml}$.

b) Numbers in columns followed by the same letter are not significantly different in Tukey HSD test at $p=0.05$ level. 


\section{Distribution of Pseudomonas solanacearum in} tomato stems after VM-A foliar sprays

All three untreated plants wilted. Bacterial populations in stems from these plants, reached $3.84 \times 10^{10} \mathrm{cfu} /$ $\mathrm{g}$ fresh weight in stem fragments excised in the first 5 $\mathrm{cm}$ from the soil line (Fig. 6). None of the three tomato plants receiving the VM-A foliar spray at $500 \mu \mathrm{g} / \mathrm{ml}$ wilted, even though $2.13 \times 10^{9} \mathrm{cfu} / \mathrm{g}$ fresh weight of bacteria were recovered from tomato stems excised from the basal $5 \mathrm{~cm}$. From stems between 30 and $35 \mathrm{~cm}$ above the soil line, $1.54 \times 10^{6} \mathrm{cfu} / \mathrm{g}$ fresh weight of bacteria were isolated from VM-A-treated plants, as opposed to $1.93 \times 10^{7} \mathrm{cfu} / \mathrm{g}$ fresh weight of control tissue.

\section{DISCUSSION}

Pot test showed that direct injection of VM-A into tomato stems gave excellent control of bacteria populations regardless of the distance of the injection site from the roots. Foliar sprays of VM-A in the field were also effective against tomato bacterial wilt. Judging from these results, VM-A is thought to be absorbed into the plant, and translocated to sites where $P$. solanacearum multiplies.

VM-A inhibited bacterial growth in vitro when trehalose was the sole carbohydrate. VM-A also inhibited bacterial growth in vivo, either directly or indirectly. Moreover, in tomato stems treated with VM-A, $P$. solanacearum populations were less than those in nontreated stems. This growth inhibition of bacteria by VM-A may cause the delay of disease symptoms.

Foliar sprays of VM-A also delayed and reduced disease symptoms of tomato bacterial wilt. Because of the soil-borne nature of the pathogen, however, no chemical can control tomato bacterial wilt completely. To effectively control tomato bacterial wilt, however, complete control of the pathogen in the soil may not be necessary. Inhibiting multiplication of the pathogen in the plant may be enough to control the disease. Therefore, direct injection of VM-A into stems was aimed at by-passing soil factors and inhibiting growth of $P$. solanacearum in the stem. Unfortunately, direct injections are not practical for large-scale applications.

VM-A was proven to be effective against tomato bacterial wilt when applied in foliar sprays, which are a more efficient, so far and more feasible method of eliminating soil complications in control.

\section{Literature cited}

1. Asano, N., Yamaguchi, T., Kameda, Y. and Matsui, K.
(1987). Effect of validamycins on glycohydrolases of Rhizoctonia solani. J. Antibiot. 40 : 526-532.

2. Buddenhagen, I. and Kelman, A. (1964). Biological and physiological aspects of bacterial wilt caused by Pseudomonas solanacearum. Annu. Rev. Phytopathol. 2 : 203-230.

3. Granada, G.A. and Sequeira, L. (1983). A new selective medium for Pseudomonas solanacearum. Plant Dis. 67 : 1084-1088.

4. Hayward, A.C. (1991). Biology and epidemiology of bacterial wilt caused by Pseudomonas solanacearum. Annu. Rev. Phytopathol. 29 : 65-87.

5. Kelman, A. (1954). The relationship of pathogenicity in Pseudomonas solanacearum to colony appearance on a tetrazolium medium. Phytopathology 44 : 693-695.

6. Shigemoto, R., Okuno, T. and Matsuura, K. (1989). Effect of validamycin A on the activity of trehalase of Rhizoctonia solani and several sclerotial fungi. Ann. Phytopathol. Soc. Jpn. 55 : 238-241.

7. Shigemoto, R., Okuno, T. and Matsuura, K. (1992). Effects of validamycin A on the growth of and trehalose content in mycelia of Rhizoctonia solani incubated in a medium containing several sugars as the sole carbohydrate. Ann. Phytopathol. Soc. Jpn. 58 : 685-690.

\section{和 文 摘 要}

石川亮・藤森健一・松浦一穂：バリダマイシンAの Pseudomonas solanacearum に対する抗菌活性とトマト青枯病 防除効果

バリダシン®の有効成分であるバリダマイシン A (VM-A) は Rhizoctonia solaniによるイネ紋枯病に卓効を示す薬剤である。 VM-A は R. solani 由来のトレハラーゼを阻害することが報告 されている。本報告では, Pseudomonas solanacearum に対する VM-A の抗菌活性と，トマト青枯病防除効果について調べた。 VM-A はトレハロースを唯一の糖源としたときのみに，P. solanacearum に対して抗菌活性を示し，その活性は増殖抑制効 果であった。トレハロース液体培地に $50 \mu \mathrm{g} / \mathrm{ml}$ の VM-A を処 理したときのP. solanacearum の増殖速度は, 培養 1 から 8 日 後までは，糖源を含まない培地のときと同程度に強く抑制され た。VM-A は温室内でのポット試験, 戒場試験で高い防除効果 を示した。固場試験で，VM-A は $250 \mu \mathrm{g} / \mathrm{ml}$ の茥葉散布（接種 5 日前预よび 2 日後)で, 接種 4 週間後に $47.4 \%$ の防除効果を示 した。無処理のトマト茎からは, 地上部から $5 \mathrm{~cm}$ の範囲で $P$. solanacearum が $3.84 \times 10^{10} \mathrm{cfu} / \mathrm{ml}$ 生重検出されたが, VM-A 処理のトマトの同部位からは病原菌は $2.13 \times 10^{9} \mathrm{cfu} / \mathrm{ml}$ 生重し か検出されなかった。以上の結果より，VM-A はトマト内での P. solanacearum の増殖を抑制することで, 青枯病の発病遅延効 果を発現するものと考えられた。 